\title{
Hubungan Kebiasaan Konsumsi Makanan Sumber Seng dan Zat Besi serta Kejadian Diare dengan Kejadian Stunting pada Balita Usia 1-3 Tahun di Wilayah Kerja Puskesmas Sungai Jering Kabupaten Merangin
}

\author{
Dwi Sriwinarsih $^{1}$, Djayusmantoko $^{2}$, Merita $^{3}$ \\ ${ }^{1-3}$ Program Studi S1 Ilmu Gizi , Sekolah Tinggi Ilmu Kesehatan Baiturrahim Jambi \\ Email : sriwinarsihdwi@gmail.com
}

Published: $14 / 03 / 2020$

\begin{abstract}
Stunting is a condition of failure to achieve physical development is measured based on height according to age. The purpose of this study was to determine the relationship of food habit consumtion of zinc and iron sources and as well as diarrhea incidence with stunting on the toddler aged 1-3 years I work of community health center of Sungai Jering, Merangin 2019 years. The study was used a Cross Sectional desigh study. This study was concucted in work area Puskesmas Sungai Jering on July 2019. The population of this study was 221 toddlers, total of sampels was 67 toddlers with the technique Proporsional Random Sampling. The data was taken using Food Frequency Questionnarie (FFQ) and interview. The data was analyzed using univariate and bivariate (Chi-Square). The result showed that 55\% of toddlers not of stunting, 51,2,\% of toddlers was rarely comsumtion of $\mathrm{Zn}$, of 53,8\% of toddlers was rarely comsumtion of $\mathrm{Fe}$, and $72,5 \%$ not diarrhea. There is significant relationship between habit comsumtion of $\mathrm{Zn}$ and incidence of stunting $(p=1,000)$, there is a significant relationship between habit comsumtion of $F e$ and incidence of stunting $(p=0,529)$ and there is a significant relationship between the the incidence of diarrhea and the incidence of stunting ( $p=0,000)$ among toddlers. There is a significant relationship between the inciedence of diarehea with the incidence of stunting. Therefore, it is advisable in mother and toddlers so can increase the nutritional knowledge about the way of eathing that is good for toddlers and maintain the cleaniness of the food so that it can improve the nutritional status of children.
\end{abstract}

Keywords: diarrhea, iron, stunting, toddlers, zinc

\begin{abstract}
Abstrak
Stunting merupakan kondisi kegagalan untuk mencapai perkembangan fisik yang diukur berdasarkan tinggi badan menurut umur. Tujuan dari penelitian ini untuk mengetahui hubungan kebiasaan konsumsi makanan sumber seng dan zat besi serta kejadian diare dengan kejadian stunting pada balita usia 1-3 tahun di wilayah kerja Puskesmas Sungai Jering, Kabupaten. Merangin Tahun 2019. Penelitian ini menggunakan desain Cross Sectional Study. Penelitian ini di laksanakan di Wilayah Kerja Puskesmas Sungai Jering pada bulan Juli 2019. Populasi penelitian yaitu 221 balita, jumlah sampel 67 balita dengan teknik pengambilan sampel yaitu Proposional Random Sampling. Data diambil menggunakan Food Frequency Questionnarie (FFQ) dan wawancara. Analisis data menggunkann uji univariat dan bivariate (Chi-Square). Hasil penelitian menunjukkan bahwa 55\% balita tidak stunting, 51,2\% memiliki kebiasaan jarang konsumsi sumber Zn, 47,5\%, kebiasaan jarang konsumsi sumber Fe dan 72,5 \% tidak mengalami kejadian diare. Tidak ada hubungan yang bermakna antara kebiasaan konsumsi sumber Zn dengan kejadian stunting pada balita $(p=1,000)$, tidak ada hubungan yang bermakna antara kebiasaan konsumsi Fe dengan kejadian stunting pada balita $(p=0,529)$ dan adanya hubungan yang bermakna antara kejadian diare dengan kejadian stunting pada balita $(p=0,000)$. Ada hubungan bermakna antara kejadian diare dengan kejadian stunting. Oleh karena itu, disarankan pada ibu balita agar meningkatkan pengetahuan gizi tentang cara pemberian makan yang baik bagi balita dan menjaga kebersihan makanan sehingga dapat meningkatkan status gizi bagi balita.
\end{abstract}

Kata kunci : balita, diare, seng, stunting, zat besi 


\section{PENDAHULUAN}

Stunting merupakan kondisi kegagalan untuk mencapai perkembangan fisik yang diukur berdasarkan tinggi badan menurut umur.Batasan stunting menurut WHO yaitu tinggi badan menurut umur dengan nilai Zscore kurang dari -2 SD (Badan Penelitian dan Pengembangan Kesehatan, 2013). Stunting merupakan suatu retardasi pertumbuhan linier yang dapat digunakan sebagai indikator untuk mengukur status gizi individu maupun kelompok masyarakat (Sudirman, 2008). Stunting juga dapat digunakan sebagai indikator untuk pertumbuhan anak yang mengindikasikan kekurangan gizi kronis (Mesfin et al, 2015).

Berdasarkan penelitian Ramli di Maluku Utara prevalensi stunting dan severe stunting lebih tinggi pada anak usia 24-59 bulan dibandingkan anak berusia 0-23 bulan. Hal tersebut sejalan dengan penelitian di Bangladesh, India, dan Pakistan dimana balita berusia 24-59 bulan yang ditemukan berada dalam resiko lebih besar pertumbuhan yang terhambat. Tingginya prevalensi stunting pada anak usia 24-59 bulan menunjukkan bahwa stunting tidak mungkin reversible. Selain itu, pada usia 3-5 tahun atau yang bisa juga disebut usia prasekolah kecepatan pertumbuhannya (growth velocity) sudah melambat (Sundari, E. 2016).

Faktor langsung yang menyebabkan stunting yaitu berupa asupan makanan dan penyakit infeksi. Asupan energi menunjukkan hubungan yang signifikan dengan kejadian stunting. Selain itu konsumsi protein, seng, dan zat besi juga turut memberikan kontribusi dalam hal ini.Protein berfungsi sebagai pembentuk jaringan baru di masa pertumbuhan dan perkembangan tubuh, memelihara, memperbaiki serta mengganti jaringan yang rusak. Anak yang mengalami defisiensi asupan protein yang berlangsung lama meskipun asupan energinya tercukupi akan mengalami pertumbuhan tinggi badan yang terhambat (Sundari, E. 2016).
Lebih dari 3 milyar orang di dunia mengalami kekurangan mikronutrien, termasuk vitamin A, zat besi dan seng.Kekurangan vitamin A meningkatkan risiko kematian 250 juta anak (WHO, 2008).Kekurangan vitamin A, selain dapat menyebabkan kebutaan, juga terbukti dapat meningkatkan risiko infeksi penyakit (Long, et al., 2007; Long, et al., 2006)).

Kekurangan zat besi menimbulkan masalah pada performan kognitif dan motorik (Unger, et al.,2007; Burden dan Westerlu, 2007; Pinero, et al., 2007; Murray-Kolb dan Beard, 2007), sedangkan kekurangan seng dilaporkan dapat menyebabkan hambatan pertumbuhan dan gangguan imunitas (Richard, et al., 2006; Hop \& Berger, 2005). Kekurangan vitamin A, zat besi dan seng sering terjadi secara simultan karena 4 faktor yang sangat mendasar. Faktor pertama, kemiskinan membatasi seseorang untuk memilih makanan kedua, faktor ekologi yang tidak menguntungkan; ketiga adalah interaksi yang sinergis dan metabolism tubuh yang pada akhirnya kekurangan salah satu mikronutrien ini akan memicu kekurangan mikronutrien yang lain; keempat, infeksi parasit, penurunan nafsu makan, dan penurunan absorsbi zat gizi yang pada akhirnya berakibat pada penurunan status mikronutrien dalam tubuh.

Diare erat hubungannya dengan keadaan kurang gizi. Setiap episode diare dapat berakibat kekurangan kemampuan menyerap sari makanan, sehingga apabila episodenya berkepanjangan akan berdampak pada peetumbuhan dan kesehatan anak. Penyakit diare sampai saat ini masih merupakan salah satu penyebab utama kesakitan dan kematian. Hampir seluruh daerah geografis dunia dan semua kelompok usia diserang diare tetapi penyakit berat dengan kematian yang tinggi terutama didapatkan pada bayi dan anakanak. Menurut penelitian sebelumnya diare menyebabkan kematian sebesar 15-34\% 
dari semua kematian, yaitu kurang lebih 300 kematian per tahun (Umbon, A, dkk, 2017).

Berdasarkan survei awal yang dilakukan dengan pengukuran $\mathrm{TB} / \mathrm{U}$ Balita di wilayah kerja puskesmas Sungai Jering terdapat $5(50 \%)$ Balita yang stunting. Kemudian dari hasil wawancara yang dilakukan menggunakan formulir frekuensi makanan pada Balita stunting, terdapat 3 (30\%) Balita yang sering mengkonsumsi makanan sumber seng dan zat besi. Oleh karena itu, peneliti tertarik untuk melakukan penelitian tentang "hubungan kebiasaan konsumsi makanan sumber seng dan zat besi serta kejadian diare dengan kejadian stunting pada balita usia 1-3 tahun di wilayah kerja Puskesmas Sungai Jering, Kec. Pangkalan Jambu, Kab. Merangin tahu 2019'

\section{METODE PENELITIAN}

Penelitian ini dilakukan dengan menggunakan desain Cross Sectional yang bertujuan untuk mengetahui hubungan kebiasaan konsumsi makanan sumber seng dan zat besi serta kejadian diare dengan kejadian stunting pada balita usia 1-3 tahun di Wilayah Kerja Puskesmas Sungai Jering, Kecamatan Pangkalan Jambu, Kabupaten Merangin, Bangko Tahun 2019.

Populasi dalam penelitian ini adalah seluruh balita yang berusia 1-3 tahun di wilayah Puskesmas Sungai Jering yang berjumlah 221 balita.Sampel pada penelitian ini diambil dari jumlah populasi yang tersedia dengan menggunakan tehnik Proporsional Random Sampling di Puskesmas Sungai Jering dengan menggunakan kuesioner yang secara langsung oleh 142 responden. Penelitian dilakukan pada bulan Juni 2019. Analisa data dengan univariat dan bivariate dengan pengujian Chi-Square.

HASIL DAN PEMBAHASAN

Hubungan Kebiasaaan Konsumsi Bahan Makanan Sumber Seng Dengan Kejadian Stunting Pada Balita
Tabel 1 menunjukkan dari 39 balita dengan kebiasaaan konsumsi bahan makanan sumber seng dengan kategori sering, frekuensi terbanyak yaitu ada 21 sampel $(53,85 \%)$ yang tidak mengalami stunting di ikuti 18 sampel $(46,15 \%)$ yang mengalami stunting. Sedangkan dari 41 balita dengan kebiasaaan konsumsi bahan makanan sumber seng dengan kategori jarang, frekuensi terbanyak yaitu ada 23 sampel $(56,1 \%)$ yang mengalami tidak stunting di ikuti 18 sampel $(43,9 \%)$ yang mengalami stunting.

Tabel 1 Hubungan Kebiasaaan Konsumsi Bahan Makanan Sumber Seng dengan Kejadian Stunting Pada Balita Di Wilayah Kerja Puskesmas Sungai Jering Tahun 2019

\begin{tabular}{lcccc}
\hline No Kategori & $\begin{array}{c}\text { Tidak stunting } \\
\mathrm{n}(\%)\end{array}$ & $\begin{array}{c}\text { Stunting } \\
\mathrm{n}(\%)\end{array}$ & $\begin{array}{c}\text { Jumlah } \\
\mathrm{n}(\%)\end{array}$ & $\begin{array}{c}\text { Nilai } \\
P\end{array}$ \\
\hline 1 Sering & 21 & 18 & 39 & 1,000 \\
Konsumsi & $(53,85)$ & $(46,15)$ & $(100)$ & \\
2 Jarang & 23 & 18 & 41 & \\
Konsumsi & $(56,1)$ & $(43,9)$ & $(100)$ \\
\hline Jumlah & 44 & 36 & 80 & \\
& $(55)$ & $(45)$ & $(100 \%)$ & \\
\hline
\end{tabular}

Hasil analisis uji chi square diperoleh nilai $p$-value $=1.000(\mathrm{p}>0,05)$. Hal ini berarti dapat diketahui bahwa tidak ada hubungan bermakna antara kebiasaan konsumsi makanan sumber zat seng (Zn) dengan kejadian stunting pada responden balita di wilayah kerja Puskesmas Sungai Jering Tahun 2019.

Berdasarkan hasil penelitian yang didapatkan, karakteristik pendidikan ibu yang tertinggi adalah berpendidikan SMA, jika pendidikan ibu tinggi diiharapkan dapat menerima segala macam informasi terutama cara pengasuhan anak yang baik dan bagaimana pemberian nutrisi pada anak. Pengetahuan mengenai sumber zat gizi dan makanan yang baik untuk keluarga berkaitan dengan pendidikan yang ditempuh seseorang. Ibu yang berpendidikan tinggi akan cenderung memilih makanan yang lebih baik dan terjamin dalam segi mutu maupun jumlahnya, dibandingkan dengan ibu yang berpendidikan rendah sehingga 
nantinya akan berpengaruh terhadap asupan makan yang diberikan kepada balita yang secara langsung akan berhubungan langsung dengan status gizi balita tersebut (Andriani, 2014).

Hasil penelitian ini sesuai dengan penelitian Margawati (2018) yang menyebutkan tidak terdapat hubungan yang signifikan antara tingkat kecukupan zat seng dengan stunting. Walaupun tingkat kebiasaan konsumsi zat seng pada balita stunting dalam kategori sering, namun zat seng yang diasup tidak semua dapat diserap oleh tubuh. Jika asupan zat besi non-heme (makanan nabati) dalam sehari sebanyak $90 \%$ yang dapat diserap hanya $17 \%$ saja. Sementara itu, untuk asupan seng jika sehari mengonsumsi 4-14 mg/hari, hanya 10-40\% saja yang dapat diserap dengan baik.

Hubungan Kebiasaaan Konsumsi Bahan Makanan Sumber Zat Besi dengan Kejadian Stunting Pada Balita

Tabel 2 Hubungan Kebiasaaan Konsumsi Bahan Makanan Sumber Zat Besi dengan Kejadian Stunting Pada Balita Di Wilayah Kerja Puskesmas Sungai Jering Tahun 2019

\begin{tabular}{lcccc}
\hline NoKategori & $\begin{array}{c}\text { Tidak } \\
\text { stunting } \\
\text { n(\%) }\end{array}$ & $\begin{array}{c}\text { Stunting } \\
\mathrm{n}(\%)\end{array}$ & $\begin{array}{c}\text { Jumlah } \\
\mathrm{n}(\%)\end{array}$ & $\begin{array}{c}\text { Nilai } \\
p\end{array}$ \\
\hline 1 Sering & 25 & 17 & 42 & 0,529 \\
Konsumsi & $(59,52)$ & $(40,48)$ & $(100)$ & \\
2 Jarang & 19 & 19 & 38 & \\
Konsumsi & $(50)$ & $(50)$ & $(100)$ & \\
\hline Jumlah & 44 & 36 & 80 & \\
& $(55)$ & $(45)$ & $(100)$ & \\
\hline
\end{tabular}

Tabel 2 menunjukkan dari 42 balita dengan kebiasaaan konsumsi bahan makanan sumber zat besi dengan kategori sering, frekuensi terbanyak yaitu ada 25 sampel $(59,52 \%)$ yang tidak mengalami stunting di ikuti 17 sampel $(40,48 \%)$ yang mengalami stunting. Sedangkan dari 38 balita dengan kebiasaaan konsumsi bahan makanan sumber zat besi dengan kategori jarang, frekuensi terbanyak yaitu ada 19 sampel $(50 \%)$ yang mengalami stunting di ikuti 19 sampel $(50 \%)$ yang tidak mengalami stunting. Hasil analisis uji chi square diperoleh nilai $p$-value $=0,264$ (p>0,05). Hal ini berarti dapat diketahui bahwa tidak ada hubungan bermakna antara kebiasaan konsumsi makanan sumber zat besi (Fe) dengan kejadian stunting pada responden balita di wilayah kerja Puskesmas Sungai Jering Tahun 2019.

Hasil pada penelitian ini menunjukkan bahwa frekuensi terbanyak yaitu kebiasaan konsumsi makanan sumber zat besi dengan kategori sering yang tidak mengalami stunting. Hasil penelitian ini dapat dikaitkan dengan karakteristik responden seperti pekerjaan ibu yang sebagian besar bekerja sebagai ibu rumah tangga. Status pekerjaan ibu juga sangat menentukan perilaku ibu dalam pemberian nutrisi kepada balita. Ibu yang bekerja berdampak pada rendahnya waktu kebersamaan ibu dengan anak sehingga asupan makan anak tidak terkontrol dengan baik dan juga perhatian ibu terhadap perkembangan anak menjadi berkurang.

Menurut Dyah (2008) dampak dari ibu bekerja juga tergantung dari jenis pekerjaan yang dilakukan ibu. Ibu yang memiliki jenis pekerjaan berat maka akan mengalami kelelahan fisik, sehingga ibu akan cenderung memilih untuk beristirahat dari pada mengurus anaknya sehingga asupan anak tidak diperhatikan dan tidak bisa tercukupi dengan baik.

Hasil penelitian ini sesuai dengan penelitian Margawati (2018) yang menyebutkan tidak terdapat hubungan yang signifikan antara tingkat kecukupan zat besi dengan stunting. Walaupun tingkat kebiasaan konsumsi zat besi pada balita dalam kategori cukup dan sering, namun zat besi yang diasup tidak semua dapat diserap oleh tubuh. Jika asupan zat besi heme (makanan hewani) dalam sehari sebanyak $10 \%$, yang dapat diserap hanya sekitar $25 \%$, sedangkan jika asupan zat besi non-heme (makanan nabati) dalam sehari sebanyak $90 \%$ yang dapat diserap hanya $17 \%$ saja. 


\section{Hubungan Kejadian Diare dengan Kejadian Stunting Pada Balita}

Berdasarkan tabel 3 dari 80 responden frekuensi terbanyak ada 41 responden $(70,68 \%)$ yang tidak memiliki kejadian diare dan tidak mengalami stunting. Sedangkan yang memiliki kejadian diare ada 19 responden $(86,36 \%)$ yang mengalami stunting.

Tabel 3 Hubungan Kejadian diare Dengan Kejadian Stunting Pada Balita Di Wilayah Kerja Puskesmas Sungai Jering Tahun 2019

\begin{tabular}{ccccc}
\hline NoKategori & $\begin{array}{c}\text { Tidak stunting } \\
\mathrm{n}(\%)\end{array}$ & $\begin{array}{c}\text { Stunting } \\
\mathrm{n}(\%)\end{array}$ & $\begin{array}{c}\text { Jumlah } \\
\mathrm{n}(\%)\end{array}$ & $\begin{array}{c}\text { Nilai } \\
p\end{array}$ \\
\hline 1 Tidak & 41 & 17 & 58 & 0,000 \\
diare & $(70,68)$ & $(29,31)$ & $(100)$ & \\
2 Iya diare & 3 & 19 & 22 & \\
& $(13,63)$ & $(86,36)$ & $(100)$ & \\
\hline Jumlah & 44 & 36 & 80 & \\
& $(55)$ & $(45)$ & $(100)$ & \\
\hline
\end{tabular}

Hasil analisis uji chi square diperoleh nilai $p$-value $=0,000(\mathrm{p}<0,05)$. Hal ini berarti dapat diketahui bahwa ada hubungan antara status gizi balita dengan kejadian diare pada responden balita di wilayah kerja Puskesmas Sungai Jering Tahun 2019.

Berdasarkan hasil tersebut terlihat bahwa kejadian diare yang dialami pada balita akan mempengaruhi kejadian stunting. Menurut Welasih (2012) salah satu faktor penyebab terjadinya stunting adalah penyakit diare. Penyakit infeksi yang disertai diare dan muntah dapat menyebabkan anak kehilangan cairan serta sejumlah zat gizi. Seorang anak yang mengalami diare akan terjadi malabsorbsi zat gizi dan hilangnya zat gizi dan bila tidak segera ditindaklanjuti dan diimbangi dengan asupan yang sesuai makan terjadi gagal tumbuh. suami yang bekerja. Kejadian diare dapat dipengaruhi oleh asupan makanan yang diberikan, keluarga dengan tingkat pendapatan yang tinggi akan lebih mudah mendapatkan asupan makanan yang lebih baik.

\section{SIMPULAN}

Berdasarkan hasil penelitian mengenai hubungan kebiasaan konsumsi makanan sumber zat seng dan zat besi serta kejadian diare dengan kejadian stunting pada balita usia 1-3 tahun di wilayah kerja Puskesmas Sungai Jering Kabupaten Merangin Tahun 2019 dapat disimpulkan balita yang memiliki kebiasaan konsumsi makanan sumber zat seng dengan kategori jarang $(51,2 \%)$ sedangkan kategori sering $(48,8 \%)$. Balita yang memiliki kebiasaan konsumsi makanan sumber zat besi dengan kategori jarang $(47,5 \%)$ sedangkan kategori sering $(52,2 \%)$. Gambaran balita yang tidak mengalami kejadian diare $(72,5 \%)$ sedangkan kategori yang mengalmi kejadi diare $(27,5 \%)$. Berdasarkan karakteristik responden sebagian besar ibu balita bekerja sebagai ibu rumah tangga dan hanya mengandalkan penghasilan dari suami. Gambaran balita yang tidak mengalami kejadian stunting (55\%) sedangkan balita yang mengalami kejadian stunting (45\%). Tidak ada hubungan bermakna antara kebiasaan konsumsi makanan sumber zat seng dengan kejadian stunting pada balita dan antara kebiasaan konsumsi makanan sumber zat besi dengan kejadian stunting pada balita. Ada hubungan bermakna antara kejadian diare dengan kejadian stunting pada balita.

Penting bagi ibu untuk memperhatikan makanan yang diberikan kepada bayi, karena makanan yang tidak sehat akan memicu terjadinya diare, dan diare akan berdampak pula pada status gizi bayi (Eptika dkk, 2019)

\section{DAFTAR PUSTAKA}

Dyah, A, 2008. Hubungan antara Pengetahuan Ibu tentang Makanan Bergizi dengan Status Gizi Balita Usia 1-3 tahun Di Desa Lencoh Wilayah Kerja Puskesmas Boyolali ,Publikasi Penelitian. Boyolali: Akbid Estu Utomo. 
Eptika I, Djayusmantoko, Merita. 2019. Hubungan Prilaku Pemberian Mp-Asi Dan Kejadian Diare Dengan Status Gizi Bayi Usia 6-11 Bulan Di Puskesmas Simpang Kawat Kota Jambi. Jurnal Akademika Baiturrahim. 8(2): 252-260.

Long, KZ., Montoya, Y., Hertzmark, E., Santos, JI., Rosado, JL. 2006. A double-blind, randomized, clinical trial of the effect of vitamin A and zinc supplementation on diarrheal disease and respiratory tract infections in children in Mexico City, Mexico13 Am J Clin Nutr ;83:693-700.

Long, KZ., Rosado, JL., Montoya, Y., de Lourdes Solano, M., Hertzmark, E., DuPont, HL., Santos, JI., 2007. Effect of Vitamin A and Zinc Supplementation on Gastrointestinal Parasitic Infections Among Mexican Children. Pediatrics;120;e846-e855.

Richard, SA., Zavaleta, N., Caulfield, LE., Black, RE., Witzig, RS., Shankar, AH. 2006. Zinc And Iron Supplementation And Malaria, Diarrhea, And Respiratory Infections In Children In The Peruvian Amazon Am. J. Trop. Med. Hyg., 75(1):126-132 Shrimpton, R., Gross, R.

Sundari , E., dan Nuryanto. 2016. Hubungan Asupan Protein, Asupan Protein, Seng, Zat Besi dan Riwayat Penyakit Infeksi Dengan Z-Score TB/U Pada Balita. Journal Of Nutrition College 5 (4): $520-529$.

Sundari, E. (2016). Hubungan Asupan Protein, Seng, Zat Besi, Dan Riwayat Penyakit Infeksi Dengan Z-Score TB/U Pada Balita (skripsi). Semarang: FK UNDIP.

Umbon, A, dkk. 2017. Hubungan Stunting Dengan Kejadian Diare Pada Siswa Siswi Sekolah Dasar Di Kecamatan Tikala Manado. Jurnal e-Clinic (ECI) Vol. 5, No 2. 